\title{
Impact Of Membership Of Financial Institutions On Rural Saving: A Micro-Level Study
}

Veena K. Pailwar, Institute of Management Technology - Nagpur, India Jaspreet Kaur, II year PGDM Student, Institute of Management Technology - Nagpur, India Khushboo Saxena, II year PGDM Student, Institute of Management Technology - Nagpur, India Mitesh Nijhara, II year PGDM Student, Institute of Management Technology - Nagpur, India

\begin{abstract}
In developing countries like India, mobilization of rural saving is necessary for inclusive growth. This micro study, aims at ascertaining the significance of financial institutions in mobilizing financial saving of rural/ semi-urban households. It is based on the primary data collected from full scale sample survey conducted in five villages and two suburban areas of National Capital Region, India. A hierarchal regression carried out on this data identified that the membership of financial institutions, specifically that of banks, insurance and informal financial institutions explains significant proportion of the variation in the rural household financial saving.
\end{abstract}

Keywords: Rural Household Saving, Membership of Financial Institutions, Determinants of Saving

\section{INTRODUCTION}

iven the importance of saving in the investment and growth process and given the importance of inclusive growth (Mohan (2006)), a number of financial institutions have been created in India catering to the demand for financial services of rural and semi-urban households (Thorat (2008)) to widen and deepen the financial markets and improve the mobilization of rural saving.

The impact of access to financial sector and financial deepening on saving has been analyzed at length in the macroeconomic studies (Beck, Levine and Loayza (2000); Chigumira and Masiyandima (2003); Diop, Dorsner and Gross, (2003); Laurenceson (2007), Asamoah (2008); Beck and Demirgüç-Kunt (2008) and Kelly and Mavrotas (2008)). However, at the microeconomic level not much work has been carried out which can gauge the impact of financial deepening, that is, greater availability of financial institutions and financial instruments on household saving (Aportela (1999) and Bending, Giesbert and Steiner (2009)).

Thus, this study aims at ascertaining the significance of membership of financial institutions in mobilizing financial saving of rural/ semi-urban households.

\section{LITERATURE SURVEY}

Existing literature gives divergent views on determinants of saving.

Keynes (1936) identified absolute disposable income as the important determinant of saving. Other two traditional theories Friedman (1957) Permanent Income Hypothesis (PIH) and Modigliani (1963) Life Cycle Hypothesis (LCH) explaining the determinants of saving point out that other variables also affect the saving of the households. Friedman (1957) PIH differentiated between permanent and transitory income and indicated that saving is influenced by both permanent and transitory income as well as present level of wealth, both human and non human. As per the Modigliani (1963) LCH the main reason for saving is to meet the expenses after the retirement and to acquire wealth. Hence, the age of the household head plays an important role in the saving behavior. 
These three traditional theories and their variants have been extensively used in the empirical studies focusing on the household saving behavior in developed and developing countries. The results obtained for the developing countries have quite often deviated from inferences derived from the studies based on the analysis of the developed countries. The micro-macro studies focused on the saving behavior of households in developed countries are based on the premises of perfect capital markets and the absence of risk aversion. Thus, these theories are found to be deficient in explaining the saving behavior of the households in developing countries where most of the households are poor, risk averse and operate in the scenario of uncertainties and imperfect financial markets.

Recent research on saving behaviour of the households in developing countries indicate that income and saving are positively associated ((Chakravarthy and Patnaik (1970); Deaton (1992); Schmidt - Hebbel, Webb and Corsetti (1992); Muradoglu and Taskin (1996); Kraay (2000) and Gardiol (2004)).

Schmidt - Hebbel, Webb and Corsetti (1992) in addition to income found wealth to be an important determinant of household saving. But this study indicated that unlike income liquid wealth, in the form of monetary asset holding, negatively affects saving. Denizer et al. (2002) indicate that accumulation of wealth which also consists of durable goods has a negative relationship with saving as there is a reduction of saving out of permanent income (Behrman and Sussangkarn (1989)). Developing countries have inefficient financial markets, which lead to accumulation of financial wealth in the form of money as a future support. As this accumulated financial wealth negatively affects saving, the developing countries have lower saving rates, than the developed countries where the financial markets are efficient (Muradoglu and Taskin (1996)). Kulikov, Paabut and Staehr (2007) considering a more comprehensive definition of wealth concluded that there is no significant effect of ownership of real estate on saving, while ownership of durable consumer goods reduces household saving. Ownership of stocks of various financial assets and liabilities, and accessibility to liquid assets affect saving negatively. However, if wealth is in the form of productive assets such as farm land, it can have a positive impact on saving. Larger land ownership helps the farmers to benefit from economies of scale and, hence, higher production and earning. Secured land ownership can be used as collateral for loans by the farmers (Gonzalez-Vega (2003) and Lamberte et al. (2006)). Credit if utilized for improving the productivity of land enhances the income level of the households, leading to higher saving. Thus, farm size can significantly and positively affect saving of farm households (Komicha (2007)).

Some studies have even considered human wealth in their analysis. For Gardiol (2004) and Kulikov, Paabut and Staehr (2007) education as a human wealth ensures employability and stability of income and, hence, it can have negative impact on saving. However, education improves awareness and financial literacy of people by enabling them to apprehend the complex procedures and formalities and associated risk and return involved in various financial instruments and institutions. For Browning and Lusardi (1996) higher financial literacy is associated with higher saving.

Impact of demographic variables is extensively studied in the literature but it is inconclusive about the impact of these variables on the household saving.

Study by Bovenberg and Evans (1990) shows that higher the old aged population in the nation, the lower is the saving rate of the economy. Whereas, a study by Foley and Pyle (2005) concludes that the young and elderly population save more than the middle aged population.

Impact of family size and the composition of the family are also uncertain on the household saving. Studies by Kelley and Schmidt (1996); Muradoglu and Taskin (1996); Masson, Bayoumi and Samiei (1998); Bloom and Williamson (1998); Loayza and Shankar (2000); Gardiol (2004) and Orbeta (2006) indicate that larger family size and larger number of children in the family reduces the saving of the households. However, in developing countries due to large family size, the intergenerational links are particularly strong, which lengthen the effective planning horizon of households (Gersovitz (1988)) and reduce the need for saving for retirement or for intergenerational transfers (Deaton (1991)).

Some studies have also analyzed the impact of occupation on saving. The occupation pursued by individuals often determines their income cycle and affects the stability and regularity of their income. Occupation with unsecured income motivates precautionary saving. Those households who have secured jobs save less than 
those who have risky jobs and uncertain income (Loayza and Shankar (2000); Gardiol (2004); Guariglia and Kim (2004) and Kulikov, Paabut and Staehr (2007)). However, study by Denizer et al. (2002) shows that, saving is not affected by source of income, that is, occupation.

Government to imbibe saving habits amongst the households often resort to forced saving mechanism in the form of compulsory saving schemes such as pension funds and insurance policies. However, the impact of such pension schemes on saving is inconclusive. On the one hand, the study by Schmidt-Hebbel (1999) argued that private saving increased by the introduction of pension reforms in Chile. On the other hand, Samwick (2000) concluded that such reforms improved the national saving in Chile but not in other reforming counties that were considered in his study. World Bank (1993) also indicated that the effect of compulsory saving i.e. government enforced compulsory saving on employees and employers on household savings varies across countries.

The impact of location has also been analyzed in the literature. Different studies have considered different definitions of location in their analysis and have identified divergent relationship with saving. Kraay (2000) concluded that locations significantly affect saving behavior whereas results of Kulikov, Paabut \& Staehr (2007) indicate that location of households in big or small towns does not significantly affect saving. Gardiol (2004) concludes that the households who live in urban areas have lower saving rates than those who live in rural areas, as the consumption expenditure in urban areas might be higher than that in the rural areas. Impact of urbanization on saving has been found to be negative by Edwards (1996) and Loayza, Schmidt-Hebbel, and Serven (2000).

Some studies have also looked into the impact of financial deepening - availability of financial institutions and instruments - on the mobilization of household saving, though not at the desired level of disaggregation. Imperfect rural financial markets negatively affect the saving of farm households. Lack of availability of financial institutions and asymmetric information deter the financial institutions from providing sufficient lending to the farm households (Pederson (2003)). This unavailability of adequate credit results in precautionary saving to maintain a constant level of consumption and deters adequate investment (Deaton (1992)).

In the context of financial deepening, the location of the financial institutions is also considered to be influencing the saving behavior of the households. World Bank (1993) pointed out that postal run saving schemes lowered transaction costs for disadvantaged savers and provided relatively safer avenue for investment and helped in fostering the mobilization of saving in many East Asian countries. Gardiol (2004) argued that the impact of access to a particular financial institution on the saving rate is positive. However, for the households, who do not have access to the financial institutions, the saving rate depends on alternative saving and investment options available to them.

Thus, it can be ascertained that household saving can be explained by various micro and macro-economic factors. Inspite of large work done in this area, literature is inconclusive regarding the magnitude and signs of impact of many of the variables which can have influence on saving.

\section{DATA AND METHODOLOGY}

\section{Data}

On the basis of literature survey and given the objective of the study the structured schedule was prepared to obtain the data on financial saving, income, landholding, occupation, literacy, membership of different financial institutions and other variables relevant for the study.

\section{Survey Methodology}

It is expected that as the rural areas move towards the urbanization, awareness and availability of financial institutions and instruments increases. Given the objective of the study, the variation in the availability of different types of financial institutions in different locations is of an utmost importance. Thus, the study selected five villages and two semi-urban areas of National Capital Region (NCR) (six villages from Delhi and one from Haryana) with varying level of development and the access to different types of institutions for the full scale sample survey which preceded by a pilot study in two villages. The distinguishing features of these villages are presented below. 
Village Kasaar in Haryana and Naya Bans in North West Delhi were two prosperous villages with almost all modern amenities in households from electricity and water supply to latest electronic instruments like television and refrigerator. Village Kanjhawla and Samaspur Khalsa in Delhi were also well to do villages with reasonably good level of literacy. Village Badarpur, amongst the selected villages was on the other extreme. The households in this village were very poor and were deprived of even basic amenities like water and electricity supply.

Razzapur and Swatantra Nagar were the semi urban areas. Razzapur was a suburb situated in the western region of Delhi with majority of its population being migrants from nearby villages. Swatantra Nagar was a suburb situated in north-west region of Delhi. The households of these two areas are engaged in only non farming activities.

Thirty households were selected randomly from each of the selected sample village resulting in total sample size of 210. The head of the households were interviewed to obtain information on the earning pattern and the saving behavior of the households. Data collection technique used was person administered survey, where a structured schedule was filled in on the basis of in-depth interviews. Each household was visited personally and the head of the household was interviewed individually to avoid the influence of responses given by one household on another and to minimize the non response rate.

\section{Econometric Model and Variables}

The impact of membership of various financial institutions, that is, bank, post office, insurance company, public provident fund (PPF) /government provident fund (GPF), mutual fund/stock market and informal financial associations, on the rural household financial saving behavior was assessed by controlling for the impact of households characteristics, like, income, landholding, occupation, family size, dependency ratio, education, family size, and locational specificities through econometric analysis.

The following functional relationship was specified for the econometric estimation.

$\ln \mathrm{S}=\mathrm{f}(\ln \mathrm{Y}, \operatorname{lnL}, \operatorname{lnF}, \ln \mathrm{W}, \mathrm{DO}, \mathrm{DE}, \mathrm{DL}, \mathrm{DB}, \mathrm{DP}, \mathrm{DI}, \mathrm{DG}, \mathrm{DS}, \mathrm{DU})$

A brief explanation of the variables used in the regression equation is presented in Table A1.

Ordinary Least Square (OLS) method using hierarchal regression technique was applied for assessing the impact of membership of financial institutions on the household financial saving.

Given the non-normality in the data and the non-linear relationship between the saving and the independent variables the $\log$ (natural $\log$ ) transformed values were considered for the econometric estimation. The transformation helped to reduce the outliers as well.

\section{Results and Findings}

The results of hierarchical regression, used for assessing the importance of the membership of various financial institutions on the rural household financial saving, are presented in Table 2. In the first step of hierarchical regression the contribution of the controlled variables was assessed (Model 1). In the next step, all the predictor variables were added to assess the contribution of these variables in explaining the variation in the rural household financial saving (Model 2).

These indicate that the predictor variables as a whole made a significant change to the explanatory power of the model. The controlled variables explained around 31 per cent of the variation (Model 1) whereas the predictor variables roughly explained additional 8 per cent of the variation (Model 2) in the financial saving. The results supported the hypothesis that overall the membership of the financial institutions can explain significant variation in the rural household financial saving.

Though a number of variables were reported to be significant and with expected signs many controlled variables such as education, landholding, family size, dependency ratio did not turn out to be significant. Suspecting multi-collinearity amongst the independent variables the values of various statistics such as zero-order correlation, partial correlation, Variance Inflation Factor (VIF) and Critical Index (CI) were examined. 
The zero order correlation and partial correlation turned out to be significant for many of the variables. However VIF values were below the cut off for all the variables indicating that multi-collinearity was not a serious problem. The CI values also indicated that multi-collinearity was not a problem except for the variable family size. The CI value (70.402) was much above the cut off for family size indicating serious multi-collinearity of this variable with other variables. Partial correlation also indicated that family size was significantly correlated with income, education and dependency ratio. Thus, the regression estimates were carried out with all the transformed values of the variables, except family size to assess whether exclusion of this variable from the regression equation made any significant difference to the results. The results of the hierarchical regression estimates carried out by excluding family size from the regression analysis (Model 3 and Model 4) indicated that exclusion of family size from the analysis did make a significant difference to the results. Apart from the other variables which were significant the dependency ratio also became significant at 5 per cent level of significance when family size was excluded from the model.

Table 1: Definitions of variables used in the econometric models

\begin{tabular}{|c|c|c|}
\hline Variable & Brief Explanation & Expected Sign \\
\hline \multicolumn{3}{|l|}{ Dependent Variable } \\
\hline Saving, $\ln S$ & $\begin{array}{l}\text { Amount of financial saving per annum in rupees by the household, count } \\
\text { variable, natural log }\end{array}$ & \\
\hline \multicolumn{3}{|l|}{ Independent Variables } \\
\hline Income, $\ln \mathrm{Y}$ & $\begin{array}{l}\text { Income earned from all the sources by all the members of the household, per } \\
\text { annum in rupees, count variable, natural log }\end{array}$ & + \\
\hline Landholding, lnL & Absolute landholding in acres, count variable, natural log & + \\
\hline Family Size, $\ln F$ & $\begin{array}{l}\text { Number of family members living in a household and using one kitchen, } \\
\text { count variable, natural log }\end{array}$ & $+/-$ \\
\hline Dependency Ratio, $\ln W$ & $\begin{array}{l}\text { Ratio of number of non-earning members to number of earning members in } \\
\text { a household using one kitchen, count variable, natural log }\end{array}$ & $+/-$ \\
\hline Occupation (Dummy, DO) & $\begin{array}{l}\text { The households having farming as the main occupation* }{ }^{*} 1 \text {; All other } \\
\text { households }=0 \text { (Representing risk taking ability), dummy variable }\end{array}$ & $+/-$ \\
\hline Education (Dummy, DE) & $\begin{array}{l}\text { The households with highest education level of } 10 \text { th class or more }=1 \text {; All } \\
\text { other households }=0 \\
\text { dummy variable }{ }^{* *}\end{array}$ & $+/-$ \\
\hline Location (Dummy, DL) & $\begin{array}{l}\text { The households having at least } 7 \text { financial institutions in } 5 \mathrm{Km} \text { radius of } \\
\text { their village }=1 \text {; Other households }=0 \\
\text { dummy variable*** }\end{array}$ & $+/-$ \\
\hline $\begin{array}{l}\text { Membership of bank } \\
\text { (Dummy, DB) }\end{array}$ & $\begin{array}{l}\text { Households that save in bank }=1 ; \text { Others }=0 \\
\text { dummy variable }\end{array}$ & + \\
\hline $\begin{array}{l}\text { Membership of post office } \\
\text { (Dummy, DP) }\end{array}$ & $\begin{array}{l}\text { Households that save in post office }=1 ; \text { Others }=0 \\
\text { dummy variable }\end{array}$ & + \\
\hline $\begin{array}{l}\text { Membership of insurance } \\
\text { company (Dummy, DI) }\end{array}$ & $\begin{array}{l}\text { Households that have taken insurance policies }=1 ; \text { Others }=0 \\
\text { dummy variable }\end{array}$ & + \\
\hline $\begin{array}{l}\text { Membership of PPF/GPF } \\
\text { (Dummy, DG) }\end{array}$ & $\begin{array}{l}\text { Households that save in Public Provident Fund / Government Provident } \\
\text { Fund }=1 \text {; Others }=0 \\
\text { dummy variable }\end{array}$ & + \\
\hline $\begin{array}{l}\text { Membership of } \\
\text { fund/ mutual } \\
\text { (Dummy, DS) }\end{array}$ & $\begin{array}{l}\text { Households that place their saving in mutual fund and/or stock market=1; } \\
\text { Others }=0 \\
\text { dummy variable }\end{array}$ & + \\
\hline $\begin{array}{l}\text { Membership of informal } \\
\text { institutions (Dummy, DU) }\end{array}$ & $\begin{array}{l}\text { Households that place their saving in any of the informal financial } \\
\text { institutions }=1 ; \text { Others }=0 \\
\text { dummy variable }\end{array}$ & + \\
\hline
\end{tabular}

Note: *Main occupation is defined as the occupation which contributes the most to the household income.

** The average value of the highest education level of all the households in all the surveyed villages was taken as the differentiating factor in case of education dummy (Average $=9.9$; approximated to 10 )

*** The average value of the financial institutions available in all the surveyed villages was taken as the differentiating factor in case of location dummy (Average $=6.14$; approximated to 7 )

The model was refined after on detection of multicollinearity in the independent variables. The family size was detected to be suffering from serious multicollinearity problem and, hence, was excluded from the regression equation. The modified regression equation used for the econometric analysis is as follows:

$\ln \mathrm{S}=\mathrm{f}(\ln \mathrm{Y}, \operatorname{lnL}, \ln \mathrm{W}, \mathrm{DO}, \mathrm{DE}, \mathrm{DL}, \mathrm{DB}, \mathrm{DP}, \mathrm{DI}, \mathrm{DG}, \mathrm{DS}, \mathrm{DU})$. 
Table 2: Regression results on transformed data

\begin{tabular}{|c|c|c|c|c|c|}
\hline & & Model 1 & Model 2 & Model 3 & Model 4 \\
\hline Constant & Coefficient & $\begin{array}{c}-19.14 \\
(-4.64) \\
* * *\end{array}$ & $\begin{array}{c}-9.26 \\
(-2.22) \\
* *\end{array}$ & $\begin{array}{c}-18.520 \\
(-4.51) \\
* * *\end{array}$ & $\begin{array}{c}-8.590 \\
(-2.06) \\
* * *\end{array}$ \\
\hline $\ln Y$ & Coefficient & $\begin{array}{c}2.52 \\
(6.38) \\
* * *\end{array}$ & $\begin{array}{c}1.50 \\
(3.71) \\
* * *\end{array}$ & $\begin{array}{c}2.346 \\
(6.233) \\
* * *\end{array}$ & $\begin{array}{c}1.326 \\
(3.423) \\
* * *\end{array}$ \\
\hline $\ln L$ & Coefficient & $\begin{array}{c}0.26 \\
(0.53)\end{array}$ & $\begin{array}{c}0.19 \\
(0.42)\end{array}$ & $\begin{array}{c}0.166 \\
(0.338)\end{array}$ & $\begin{array}{c}0.103 \\
(0.226)\end{array}$ \\
\hline $\ln F$ & Coefficient & $\begin{array}{c}-0.98 \\
(-1.42)\end{array}$ & $\begin{array}{c}-0.94 \\
(-1.48)\end{array}$ & - & - \\
\hline $\ln W$ & Coefficient & $\begin{array}{c}-0.42 \\
(-0.73)\end{array}$ & $\begin{array}{c}-0.88 \\
(-1.67) \\
*\end{array}$ & $\begin{array}{c}-0.89 \\
(-1.928) \\
*\end{array}$ & $\begin{array}{c}-1.339 \\
(-) 3.119 \\
* * *\end{array}$ \\
\hline DO & Coefficient & $\begin{array}{c}0.09 \\
(0.09)\end{array}$ & $\begin{array}{c}-0.02 \\
(-0.02)\end{array}$ & $\begin{array}{c}0.255 \\
(0.248)\end{array}$ & $\begin{array}{c}0.15 \\
(0.159)\end{array}$ \\
\hline DE & Coefficient & $\begin{array}{c}-0.48 \\
(-0.73)\end{array}$ & $\begin{array}{c}1.04 \\
(-1.67) \\
* \\
\end{array}$ & $\begin{array}{c}-0.224 \\
(-0.351)\end{array}$ & $\begin{array}{c}-0.8 \\
(-1.331)\end{array}$ \\
\hline DL & Coefficient & $\begin{array}{c}0.71 \\
(1.17)\end{array}$ & $\begin{array}{c}1.32 \\
(2.28) \\
* *\end{array}$ & $\begin{array}{l}0.847 \\
(1.42)\end{array}$ & $\begin{array}{c}1.48 \\
(2.609) \\
* * *\end{array}$ \\
\hline DB & Coefficient & & $\begin{array}{c}2.06 \\
(3.73) \\
* * *\end{array}$ & & $\begin{array}{c}2.035 \\
(3.673) \\
* * *\end{array}$ \\
\hline DP & Coefficient & & $\begin{array}{c}-0.24 \\
(-0.31)\end{array}$ & & $\begin{array}{c}-0.296 \\
(-0.389)\end{array}$ \\
\hline DI & Coefficient & & $\begin{array}{c}2.15 \\
(3.54) \\
* * *\end{array}$ & & $\begin{array}{c}2.158 \\
(3.55) \\
* * *\end{array}$ \\
\hline DG & Coefficient & & $\begin{array}{c}1.35 \\
(1.53) \\
\end{array}$ & & $\begin{array}{c}1.518 \\
(1.737) \\
\end{array}$ \\
\hline DS & Coefficient & & $\begin{array}{c}-0.73 \\
(-0.53) \\
\end{array}$ & & $\begin{array}{c}-0.82 \\
(-0.596) \\
\end{array}$ \\
\hline DU & Coefficient & & $\begin{array}{c}1.88 \\
(2.98) \\
* * *\end{array}$ & & $\begin{array}{c}1.837 \\
(2.902) \\
* * *\end{array}$ \\
\hline R square & & 0.314 & 0.454 & & 0.448 \\
\hline F value & & 13.215 & 12.518 & & 13.3 \\
\hline R square change & & & 8.343 & & 8.339 \\
\hline Sig. F change & & .000 & .000 & & 0.000 \\
\hline
\end{tabular}

Note: $* * *, * *, *$ represent significance at 1 per cent, 5 per cent and 10 per cent respectively.

Figures in parentheses indicate t-values.

As indicated above the CI values were below the critical levels for variables other than family size, but for many of these variables the partial correlation was significant. To assess whether these significant correlation were making the results biased some more regression were run where each time one of the variable or combination of variables were dropped from the model and the results were compared with the results of Model 2. Exclusion of landholding, occupation, education, membership of post office, public provident fund, mutual funds and stock markets did not make significant changes to the results. Thus, it was decided to retain these variables in the model. Regression results based on Model 4 (consisting of all the variables - controlled as well as predictors except family size) indicate the relationship of income, landholding, dependency ratio, occupation dummy and location dummy with saving with expected sign. Income, landholding, occupation dummy and location dummy had a positive relation with saving, whereas, dependency ratio had a negative relation with saving. However, education dummy appeared with a negative sign indicating that households with an education level of at least tenth standard save less 
compared to those households with education level of less than tenth standard. However, education was found insignificant in the villages considered in the study and, hence, its sign is not of relevance.

Considering the relationship of membership of financial institutions with saving, membership of bank, insurance, PPF and informal financial institutions had, as expected, a positive relation with saving. However, memberships of post office, mutual fund/ stock market had a negative relationship. The counterintuitive signs for post office and mutual fund/stock market are not much of relevance as both of these factors turned out to be insignificant in explaining the rural saving behavior.

\section{CONCLUSION}

This study aimed at ascertaining the significance of financial institutions in mobilizing rural saving in India. Five villages and two semi-urban areas from North India, located in NCR of Delhi, were selected for the cross sectional study.

The controlled variables, such as, income, dependency ratio and location explained significant proportion of the variation in financial rural households saving. As well elaborated in the existing literature, income and location had significant positive influence whereas dependency ratio had significant negative influence on the saving.

The results of the econometric analysis supported the hypothesis that the membership of financial institutions explains significant proportion of the variation in the rural household financial saving. Membership of some of the financial institutions like, banks, insurance, and informal financial institutions has a significant positive influence than the other financial institutions on the financial saving of rural households.

Thus, it can be concluded that the presence of and membership of financial institutions helps in mobilizing the rural financial saving in the economy's financial system and the efforts should be made to further enhance the participation of the rural households in these financial institutions. Also, efforts to increase the household income, to reduce the dependency ratio and to increase the number of financial institutions, specially, banks, insurance and informal financial institutions, within the $5 \mathrm{Km}$ radius of the villages, can prove to be fruitful in mobilizing rural household saving into the economy's financial system.

\section{AUTHOR INFORMATION}

Veena Pailwar is currently associated with the Institute of Management Technology, Nagpur (India) as a Professor of Economics.

Khushboo Saxena is a Post Graduate Diploma in Management from Institute of Management Technology - Nagpur (India). Currently she is associated with Life Insurance Corporation of India as Asst. Administrative Officer.

Jaspreet Kaur is a Post Graduate Diploma in Management from Institute of Management Technology - Nagpur (India). At present she is working with IDBI Bank Ltd. as an Asst. Manager.

Mitesh Nijhara is a Post Graduate Diploma in Management from Institute of Management Technology - Nagpur (India). Currently he is working as an assistant manager - HR with Hindustan National Glass and Industries Ltd.

\section{REFERENCES}

1. Aportela, F. (1999), Effects of Financial Access on Savings by Low Income People, Banco de Mexico, Research Department, Mimeo, December.

2. Asamoah, G. N. (2008), The Impact of the Financial Sector Reforms on Savings, Investments and Growth of Gross Domestic Product (GDP) in Ghana, International Business and Economics Research Journal, October, 7(10): 73-84 
3. Beck, T. and Demirgüç-Kunt, A. (2008), Access to Finance, The World Bank Economic Review, November, 22 (3), 383-396.

4. Beck, T., Levine, R. and Loayza, N. (2000), Finance and Sources of Growth, Journal of Financial Economics, 58(1-2), 261-300.

5. Behrman, J., and Sussangkarn, C. (1989), Do the Wealthy Save Less?, Philadelphia, Pa.: Department of Economics, University of Pennsylvania.

6. Bending, M., Giesbert, L. and Steiner, S. (2009), Saving, Credit and Insurance: Household Demand for Formal Financial Services in Rural Ghana, GIGA Working Paper 94, January.

7. Bloom, D.E. and Williamson, J.G. (1998), A Demographic Transition and Economic Miracles in Emerging Asia, World Bank Economic Review, 12(3): 419-455.

8. Bovenberg, A. L., and Evans, O. (1990), National and Personal Saving in the United States: Measurement and Analysis of Recent Trends, IMF Staff Papers, 37(3), September.

9. Browning M. and Lusardi A. (1996), Household Saving: Micro Theories and Micro Facts, Journal of Economic Literature, 34(4): 1797-1855.

10. Chakravarthy, C.K. and Patnaik, R.R. (1970), Income Distribution and Saving Investment Pattern of Cultivating Households, Indian Journal of Agricultural Economics, 25(3).

11. Chigumira, G. and N. Masiyandima, (2003), Did Financial Sector Reform Result in Increased Savings and Lending for the SMEs and the Poor?, IFLIP Research Paper No 03-7. International Labour Office. Geneva.

12. Deaton, A. (1991), Saving and Liquidity Constraints, Econometrica, $59: 1121-1142$.

13. Deaton, A. (1992), Understanding Consumption, Oxford: Oxford University Press.

14. Denizer, C., Wolf, H. and Ying, Y, (2002), Household Saving in Transition Economies, Journal of Comparative Economics, 30(3): 463-475.

15. Diop, C., Dorsner, C. and Gross, D.M. (2003), Understanding Saving Mobilization by Mutual Savings and Loan Institutions in WAEMU Countries, IFLIP Research Paper 03-11, International Labour Office. Geneva.

16. Edwards, S. (1996), Why are Latin America's Saving Rates So Low? An International Comparative Analysis, Journal of Development Economics, October, 51(1): 5-44.

17. Foley, M. and Pyle, W., (2005), Household Savings in Russia during the Transition, Middlebury College Economics, Discussion Paper, No. 05-22.

18. Friedman, M. (1957), A Theory of the Consumption Function, Princeton: Princeton University Press.

19. Gardiol, A.K. (2004), Les determinants de l'epargne et des choix d'investissement des ménages au Nicaragua, Departement d'Econometrie et d'Economie Politique, Universite de Lausanne, March.

20. Gersovitz, M. (1988), Saving and Development, Handbook of Development Economics, Chenery, H.B. and Srinivasan, T.N. (ed.), Vol.1, Elsevier Science Publishers: 382-424.

21. Gonzalez-Vega, C. (2003), Deepening Rural Financial Markets: Macroeconomic Policy and Political Dimensions, Paving the Way Forward: An International Conference on Best Practices in Rural Finance, Washington D.C, June.

22. Guariglia, A. and Kim, B.J., (2004), Earnings Uncertainty, Precautionary Saving, and Moonlighting in Russia, Journal of Population Economics, 17(2): 289-310.

23. Kelly, R. and Mavrotas, G. (2008), Saving and Financial Sector Development: Panel Cointegration Evidence from Africa, The European Journal of Finance, 14 (7): 563-581.

24. Kelley, A.C. and Schmidt, R.M. (1996), Saving, Dependency and Development, Journal of Population Economics, 9(4):365-386.

25. Keynes, J.M. (1936), The General Theory of Employment, Interest and Money, New York: Harcourt, Brace \& Co.

26. Komicha, H.H. (2007), Farm Household Economic Behaviour in Imperfect Financial Markets: Empirical Evidence and Policy Implications on Saving, Credit and Production Efficiency in Southeastern Ethiopia, Doctoral Thesis, Swedish University of Agriculture Sciences, Uppsala.

27. Kraay, A. (2000), Household Saving in China, The World Bank Economic Review, 14(3):545-570.

28. Kulikov, D., Paabut, A. and Staehr, K. (2007), A Microeconometric Analysis of Household Saving in Estonia: Income, Wealth and Financial Exposure, Research Department Eesti Pank, May.

29. Lamberte, M. B., Vogel, R. C., Moyes, R.T. and Fernando, N.A. (Eds.) (2006), Beyond Microfinance: Building Inclusive Rural Financial Markets in Central Asia, Asian Development Bank. 
30. Laurenceson, J. (2007), Financial Sector Regulation, Bank Franchise Values and Savings Mobilisation, Applied Economics, March, 39(4): 519-525.

31. Loayza, N., Schmidt-Hebbel, K. and Serven, L. (2000), Saving in Developing Countries: An Overview, The World Bank Economic Review, 14(3): 393-414.

32. Loayza, N., and Shankar, R. (2000), Private Saving in India, The World Bank Economic Review, 14(3):571594.

33. Masson, P., Bayoumi, T. and Samiei, H. (1998), International Evidence on the Determinants of Private Saving, The World Bank Economic Review, 14(3):393-414.

34. Modigliani, F. (1963), The Life-Cycle Hypothesis of Saving: Aggregate Implications and Tests, American Economic Review, 53(1)(1):55-84.

35. Mohan, R. (2006), Economic Growth, Financial Deepening and Financial Inclusion, Address to the Annual Bankers' Conference at Hyderabad 2006 on November 3.

36. Muradoglu, G. and Taskin, F. (1996), Differences in Household Savings Behaviour: Evidence from Industrial and Developing Countries, The Developed Economies, 34(2):138-153.

37. Orbeta, A.C. (2006), Children and Household Saving in the Philippines. Philippine Institute for Development Studies, Discussion Paper, Series No. 2006- 14.

38. Pederson, G. (2003), Rural Finance Institutions, Markets and Policies in Africa, Pre-IAAE Conference on African Agricultural Economics, Bloemfontein, South Africa. August 13-14.

39. Samwick, A. (2000), Is Pension Reform Conducive to Higher Saving?, Review of Economics and Statistics, 82(2): 264-72.

40. Schmidt-Hebbel, K. (1999), Chile's Pension Revolution Coming of Age, in Reforming the Pension System, What Germany can Learn from Other Countries (ed.), Deutsches Institut fur Altersvorsorge, Cologne.

41. Schmidt-Hebbel K., Webb S.B., and Corsetti G. (1992), Household Saving in the Developing Countries: First Cross Country Evidence, World Bank Economic Review, 6(3):529-47.

42. Thorat, U. 2008. Financial Inclusion and Information Technology. RBI Bulletin October, 1643-1648.

43. World Bank (1993), The East Asian Miracle: Economic Growth and Public Policy. A World Bank Policy Research Report, New York: Oxford University Press. 


\section{NOTES}

